\title{
PERAN KEPUASAN PELANGGAN MEMEDIASI KUALITAS PRODUK DAN PERSEPSI HARGA DENGAN LOYALITAS PELANGGAN
}

\author{
Made Indira Sari Parthady ${ }^{1}$ \\ I Ketut Rahyuda ${ }^{2}$ \\ ${ }^{1,2}$ Fakultas Ekonomi dan Bisnis Universitas Udayana (Unud), Bali, Indonesia \\ E-mail:indiraparthady@gmail.com
}

\begin{abstract}
ABSTRAK
Tujuan dari penelitian ini untuk menguji pengaruh kualitas produk dan persepsi harga dengan loyalitas pelanggan melalui keepuasan pelanggan pada konsumen produk Miniso. Jumlah sampel yang diambil sebanyak 105 pada konsumen produk Miniso yang memiliki kriteria pernah melakukan pembelian produk Miniso, berdomisili di Kota Denpasar, dan berpendidikan terakhir SMA. Data dikumpulkan melalui penyebaran kuesioner. Teknik analisis yang digunakan adalahpath analysis. Berdasarkan hasil analisis ditemukan bahwa variabel kualitas produk berpengaruh positif dan signifikan terhadap kepuasan pelanggan pada konsumen produk Miniso, variabel persepsi harga berpengaruh positif dan signifikan terhadap kepuasan pelanggan pada konsumen produk Miniso, variabel kualitas produk berpengaruh positif dan signifikan terhadap loyalitas pelanggan pada konsumen produk Miniso, variabel persepsi harga berpengaruh positif dan signifikan terhadap loyalitas pelanggan pada konsumen produk Miniso, variabel kepuasan pelanggan berpengaruh positif dan signifikan terhadap loyalitas pelanggan pada konsumen produk Minisodi Kota Denpasar.
\end{abstract}

Kata Kunci: kualitas produk, persepsi harga, kepuasan pelanggan, loyalitas pelanggan

\section{ABSTRACT}

The purpose of this study is to examine the effect of product quality and price perceptions on customer loyalty through keeping customer satisfaction with Miniso product consumers. The number of samples taken was 105 in Miniso product consumers who had the criteria to have purchased Miniso products, domiciled in Denpasar City, and were last educated in high school. Data was collected through questionnaires. The analysis technique used is the sobel test using path analysis. Based on the results of the analysis it was found that product quality variables had a positive and significant effect on customer satisfaction on Miniso product consumers, the price perception variable had a positive and significant effect on customer satisfaction on Miniso product consumers, product quality variables had a positive and significant effect on customer loyalty to Miniso product consumers. Price perception variables have a positive and significant effect on customer loyalty to Miniso product consumers, and customer satisfaction variables have a positive and significant effect on customer loyalty to Miniso product consumers in Denpasar City.

Keywords: product quality, price perception, customer satisfaction, customer loyalty 


\section{PENDAHULUAN}

Salah satu gerai ritel asing yang saat ini sedang berkembang pesat di Indonesia adalah peritel dari Jepang yaitu Miniso. Di tengah gencarnya pertumbuhan sektor ritel asing di Indonesia, Miniso justru semakin agresif dalam memperluas pasarnya di Indonesia. Dilansir dari JPNN (2017), hanya dalam tempo 8 bulan, bisnis ritel Miniso sudah membuka 50 gerai di Indonesia pada tahun 2017 dan gerai tersebut tersebar di kota-kota besar. Pada Juni 2017 Miniso membuka gerai pertama di Kota Denpasar tepatnya di Plaza Renon. Miniso merupakan peritel yang fokus kepada peralatan rumah tangga dan barang konsumsi dengan gerai ritel berbentuk supermarket dan produk-produk yang ditawarkan oleh Miniso unggul dengan harga produknya yang murah, dan kualitas produk dijamin baik. Harga produk Miniso yang paling murah yaitu Rp 15.000 sampai harga yang paling mahal yakni sekitar Rp 400.000 (Tribun Bali, 2017). Dilansir dari situs resminya, Miniso juga telah memenangkan "The 2018 iF Design Award" yaitu penghargaan bagi produk terbaik dilihat dari estetika produk, kualitas produk, pemilihan material, inovasi teknologi, fungsionalitas, dan faktor lain yang mempengaruhi pengalaman pengguna produk (Miniso, 2018).

Perkembangan produk Miniso juga dapat dilihat melalui adanya peningkatan volume penjualan produk Miniso setiap tahunnya, hal ini ditunjukkan pada Tabel 1 mengenai volume penjualan produk Miniso dari tahun 2015 sampai 2017. 
Tabel 1.

Volume Penjualan Produk MinisoTahun 2015 - 2017

\begin{tabular}{cc}
\hline Year & Sales Volume \\
\hline 2015 & USD 750 million \\
2016 & USD 1.5 billion \\
2017 & USD 1.8 billion \\
\hline
\end{tabular}

Sumber:www. miniso.com, 2018

Tabel 1 menunjukkan volume penjualan Miniso secara global terus mengalami peningkatan. Dari sekian banyak outlet resmi Miniso yang ada di berbagai macam negara, di Indonesia memiliki tingkat penjualan paling tinggi dibandingkan negara lainnya. Dilansir dari www.kontan.co.id (2017), rata-rata transaksi harian penjualan Miniso di Indonesia berkisar antara US\$ 1.000 -US\$ 2.000 atau sekitar Rp 13 juta - Rp 26 juta. Tercatat transaksi tertinggi sebesar US\$ 19.000 atau sekitar Rp 247 juta per hari pernah terjadi di gerai Miniso di Lippo Mall Puri Jakarta Barat. Kemudian gerai di Margo City Depok tercatat pernah mencetak transaksi US\$ 12.000 per hari atau sekitar Rp 156 juta per hari.

Retail Miniso di Kota Denpasar sudah tidak asing lagi khususnya bagi penduduk Kota Denpasar yang berusia remaja sampai dewasa. Dilihat dari hasil pra survey yang telah dilakukan oleh peneliti pada 15 responden yang seluruhnya adalah mahasiswa, seluruh responden menyatakan pernah membeli produk Miniso. Seluruh responden tersebut menyatakan bahwa harga yang diberikan produk Miniso murah dan memuaskan. Dari 15 responden tersebut, 12 responden menyatakan bahwa kualitas produk Miniso sangat baik dan 3 responden menyatakan bahwa kualitas produk Miniso sudah cukup baik dan menyarankan untuk lebih meningkatkan kualitas dari produk Miniso. Melihat perkembangan bisnis ritel Miniso yang pesat, tentu akan menarik pesaing untuk membuka gerai 
ritel serupa atau meniru konsep bisnis Miniso dengan menjual produk fashion dan lifestyle dengan konsep Jepang.

Demi mempertahankan bisnisnya dari pesaing, Miniso harus menentukan strategi yang tepat agar pelanggan tidak beralih ke merek yang lain. Strategi pemasaran adalah himpunan asas yang secara tepat, konsisten, dan layak dilaksanakan oleh perusahaan guna mencapai sasaran pasar yang dituju (target market) dalam jangka panjang dan tujuan perusahaan jangka panjang (objectives), dalam situasi persaingan. Untuk itu, kegiatan dalam pemasaran industri bisnis harus direncanakan sesuai strategi yang optimal. Strategi yang dapat dilakukan perusahaan untuk memenangkan persaingan dalam bisnis retail terletak pada kemampuan perusahaan menciptakan keunggulan kompetitif. Keunggulan kompetitif akan membentuk loyalitas pelanggan dan membuka peluang untuk melakukan ekspansi pasar (Pudyanarti, 2016). Saat ini, mempertahankan loyalitas pelanggan lebih diutamakan oleh perusahaan daripada mendapatkan pelanggan baru karena keberhasilan jangka panjang dari suatu merek tertentu tidak lagi didasarkan hanya pada jumlah pelanggan yang melakukan pembelian, tetapi pada jumlah pelanggan yang melakukan pembelian ulang.

Loyalitas konsumen terhadap suatu merek terjadi ketika merek tersebut dapat dianggap positif dan dipercaya setelah pelanggan membeli produk pada merek tersebut sehingga pelanggan membeli kembali produk pada merek tersebut (Rizwan, 2014). Kotler dan Keller (2012) mendefinisikan loyalitas pelanggan sebagai komitmen yang dipegang teguh untuk kembali membeli produk atau jasa yang disukai dimasa depan, meskipun pengaruh situasional dan upaya pemasaran 
pada saat itu memiliki potensi untuk menyebabkan pelanggan beralih ke produk lain. Loyalitas pelanggan tercipta melalui kepuasan pelanggan atas produk yang dikonsumsi, dimana pelanggan merasa harapannya terpenuhi sehingga mengarah kepada loyalitas. Sangat penting dalam sebuah usaha bisnis untuk bisa membangun, mempertahankan hingga meningkatkan loyalitas pelanggannya. Loyalitas pelanggan adalah pandangan pelanggan untuk membeli kembali sesuatu berdasarkan harapan mereka dan pengalaman dari masa lalu. Loyalitas pelanggan adalah pola pikir yang memaksa pelanggan untuk menggunakan kembali produk dan jasa atau merek lagi dan lagi.

Lovelock dan Wirtz (2016:338) menyebutkan bahwa loyalitas pelanggan berperan untuk meningkatkan kinerja keuangan dan mempertahankan kelangsungan hidup perusahaan. Kesetiaan pelanggan didefinisikan sebagai komitmen yang dipegang teguh untuk mempersonalisasikan layanan produk secara konsisten di masa depan, meskipun ada pengaruh situasional dan upaya pemasaran yang berpotensi menyebabkan peralihan perilaku (Marakanon dan Panjakajornsak, 2016).

Besarnya pengaruh loyalitas pelanggan terhadap perusahaan mengharuskan perusahaan untuk mampu memberikan produk yang berkualitas demi memuaskan pelanggannya. Kualitas produk merupakan faktor penting yang harus diperhatikan perusahaan untuk mendapatkan loyalitas pelanggan karena sebelum pelanggan melakukan proses pembelian produk atau jasa, loyalitas pelanggan tidak akan begitu saja terbentuk. Loyalitas pelanggan bisa terbentuk dengan adanya kesan dari kualitas maupun pengalaman saat mengkonsumsi barang maupun jasa. 
Kualitas produk merupakan kecocokan pelanggan terhadap sebuah produk yang bisa diharapkan dan memenuhi kebutuhannya (Caesar, 2016).Semakin perusahaan memberikan produk yang berkualitas maka kepuasan yang dirasakan oleh pelanggan akan semakin tinggi sehingga kualitas produk itu sendiri mempengaruhi aspek bagaimana nantinya pelanggan akan selalu loyal terhadap suatu merek. Pada penelitian terdahulu yang telah dilakukan Peter et al. (2014), Zohaib Ahmed (2014), dan Howat (2013) menyatakan hasil yang sama bahwa kualitas produk memiliki pengaruh yang positif dan signifikan terhadap loyalitas pelanggan, maka semakin pelanggan puas terhadap kualitas produk yang dirasakan akan meningkatkan tingginya tingkat loyal pelanggan terhadap merek tesebut. Meskipun demikian, terdapat penelitian yang menyatakan bahwa kualitas produk tidak memiliki pengaruh terhadap loyalitas konsumen. Rimawan et al. (2017)menunjukkan bahwa kualitas produk tidak berpengaruh pada loyalitas pelanggan pada PT ABC Tbk, dimana pelanggan tidak peduli dengan kemampuan kemasan produk PT ABC yang fleksibel sehingga kualitas produk tidak mempengaruhi kepuasan dan loyalitas pelanggan.

Persepsi harga juga menjadi faktor penting yang harus diperhatikan oleh perusahaan terutama perusahaan dalam bentuk ritel. Harga dianggap sebagai salah satu faktor penting bagi perusahaan, sehingga setiap perusahaan sebaiknya mempertimbangkan secara matang setiap keputusan dalam masalah harga. Dalam mencapai loyalitas pelanggan, perusahaan harus dapat memberikan harga yang sesuai kepada pelanggan. Menurut Prasastono et al. (2017), murah atau mahalnya harga suatu produk sangat relatif sifatnya tergantung persepsi masing-masing 
pelanggan, untuk itu perusahaan harus selalu memonitor harga yang ditetapkan oleh para pesaing, agar harga yang ditentukan perusahaan tersebut tidak terlalu tinggi, sehingga dapat menciptakan loyalitas pelanggan. Ketika pelanggan memiliki persepsi harga y ang baik setelah melakukan pembelian pertama, maka pelanggan akan konsisten untuk melakukan pembelian ulang pada merek yang sama di waktu yang akan datang. Hal ini dibuktikan pada penelitian yang dilakukan Samahet al. (2013) yang menyatakan bahwa terdapat pengaruh positif antara persepsi harga terhadap loyalitas pelanggan pada restoran makanan cepat saji di Penang. Begitu juga dengan penelitian yang telah dilakukan, Sedjai Asma (2018), Fata (2015) dan Nur Laely (2016), dimana persepsi harga diduga berpengaruh positif dan signifikan terhadap loyalitas pelanggan. Namun, penelitian Aseead dan Noermijati (2013) menyebutkan bahwa harga tidak berpengaruh terhadap loyalitas pelanggan secara langsung, tetapi harga memiliki pengaruh terhadap loyalitas pelanggan secara tidak langsung melalui kepuasan pelanggan sehingga variabel kepuasan pelanggan sebagai variabel mediasi. Ketika harga yang diberikan baik tinggi atau rendah namun tetap dibarengi dengan pengharapan yang tinggi maka pelanggan akan merasakan suatu kepuasan terhadap produk tersebut. Pelanggan dapat beralih ke merek lain apabila harga yang ditentukan tidak sesuai dengan manfaat yang pelanggan terima sehingga membuat pelanggan tidak puas.

Kepuasan pelanggan akan menjadi faktor utama sebagai tujuan perusahaan untuk mempertahankan kelangsungan hidup perusahaan dalam pasar bisnis dan mampu meningkatkan keunggulan dalam persaingan. Jika ingin mendapatkan 
loyalitas pada pelanggan maka hal pertama yang perlu dilakukan adalah menciptakan kepuasan. Kotler (2003) dalam Praharsi et al. (2015) mendefinisikan kepuasan pelanggan adalah perasaan senang atau kecewa seseorang yang berasal dari perbandingan antara kesannya terhadap kinerja (atau hasil) suatu produk dengan harapan-harapannya.Terciptanya kepuasan pelanggan akan memberikan manfaat, yaitu hubungan antara perusahaan dan pelanggan menjadi baik dan tercipta loyalitas pelanggan hal ini didukung penelitian Edward Makwei (2014) yang menyatakankepuasan pelanggan mampu meningkatkan loyalitas pelanggan. Setelah mengkonsumsi suatu produk atau jasa, pelanggan akan memiliki perasaan puas atau tidak puas terhadap produk atau jasa yang dikonsumsinya (Sangadji dan Sopiah, 2013:190). Dengan adanya pemahaman yang tinggi akan suatu kepuasan dapat menjadi masukan dan pengetahuan yang baik bagi perusahaan Miniso dalam rangka meningkatkan loyalitas pelanggan dan mencapai keunggulan kompetitif.

Berry (2007:1) menyebutkan sepuluh faktor penentu kepuasan (ten domains of satisfaction) yang mempengaruhi perilaku kepuasan pelanggan, salah satunya adalah kualitas produk. Ditemukan dalam penelitian Haryanto (2013) bahwa kualitas produk berpengaruh signifikan terhadap kepuasan pelanggan. Penelitian menurut Lasander (2013) menyatakan adanya pengaruh yang signifikan kualitas produk dodol daging pala audia di Tahuna Kabupaten Sangihe terhadap kepuasan pelanggan. Penelitian Ismail et al. (2016) menemukan bahwa peningkatan kualitas produk yang kompetitif dapat meningkatkan kepuasan pelanggan. Kualitas produk memiliki pengaruh positif terhadap kepuasan pelanggan dikemukakan pada 
penelitian yang dilakukan oleh Nuridin (2018) dan Tumangkeng (2013), namun terdapat penelitian yang menunjukkan hasil negatif dan tidak signifikan antara kualitas produk dan kepuasan pelanggan (Noor Hafiza, 2017; Segoro, 2013). Berdasarkan hasil penelitian yang telah dikemukakan, maka pada penelitian ini hipotesis yang dapat ditarik sebagai berikut:

$\mathrm{H}_{1} \quad$ : Kualitas produk berpengaruh positif dan signifikan terhadap kepuasan pelanggan.

Malik dan Yaqoob (2012:487) persepi harga adalah sebuah proses dimana pelanggan menafsirkan nilai harga dan atribut ke barang atau pelayanan yang diinginkan. Penelitian Ismail et al. (2016) menemukan bahwa harga yang kompetitif dapat meningkatkan kepuasan pelanggan, hal ini juga didukung oleh studi dari Ehsani dan Ehsani (2015), mereka mengatakan bahwa harga dapat meningkatkan kepuasan pelanggan. Penelitian yang telah dilakukan Arnindita (2016) dan Fata (2015) juga menunjukkan hasil bahwa variabel harga secara simultan berpengaruh positif dan signifikan terhadap kepuasan pelanggan, namun berbeda dengan penelitian yang telah dilakukan Amir et al. (2013) menunjukkan hasil negatif dan tidak signifikan antara variabel harga terhadap kepuasan konsumen. Berdasarkan hasil penelitian yang telah dikemukakan, maka pada penelitian ini hipotesis yang dapat ditarik sebagai berikut:

$\mathrm{H}_{2}$ : Persepsi harga berpengaruh positif dan signifikan terhadap kepuasan pelanggan.

Menurut Sangadji dan Sopiah (2013:116) dalam Caesar (2015), secara ringkas manfaat dari kualitas yang superior salah satunya adalah loyalitas pelanggan yang lebih besar. Dalam penelitian yang dilakukan Caesar (2015); 
Kurniawati et al. (2014); Sembiring et al. (2014), Irawan dan Japarianto (2013); dan Pongoh (2013) menyatakan ada pengaruh secara langsung kualitas produk terhadap loyalitas pelanggan, namun berbeda dengan penelitian Rimawan et al. (2017) yang menunjukkan riset gap dimana kualitas produk tidak berpengaruh pada loyalitas pelanggan. Berdasarkan hasil penelitian yang telah dikemukakan, maka pada penelitian ini hipotesis yang dapat ditarik sebagai berikut:

$\mathrm{H}_{3}$ : Kualitas produk berpengaruh positif dan signifikan terhadap loyalitas pelanggan.

Secara teoritis hubungan antara strategi harga dengan loyalitas pelanggan, ditunjukkan oleh pendapat Harald dalam Surya dan Setyaningrum (2009:19) yang menyatakan konsep harga berhubungan dengan profitabilitas produk, tingkat harga kompetitif, dan syarat-syarat pembelian. Pelangganakanloyal jika perusahaan menetapkan harga produk yang sebanding dengan nilai manfaat yang diberikan kepada pelanggan.

Penelitian yang dilakukan Asadi et al. (2014); Fata (2015); dan Nur Laely (2016) menunjukkan harga diduga berpengaruh positif dan signifikan terhadap loyalitas pelanggan, namun penelitian Sulistyanto (2015) menunjukkan persepsi harga tidak berpengaruh terhadap loyalitas pelanggan, sehingga loyalitas pelanggan tidak akan berpengaruh apa-apa dengan adanya peningkatan persepsi harga. Berdasarkan hasil penelitian yang telah dikemukakan, maka pada penelitian ini hipotesis yang dapat ditarik sebagai berikut:

$\mathrm{H}_{4}$ : Persepsi harga berpengaruh positif dan signifikan terhadap loyalitas pelanggan.

Sangadji dan Sopiah (2013:190) menyebutkan bahwa terciptanya kepuasan pelanggan akan akan memberikan manfaat, yaitu hubungan antara perusahaan dan 
pelanggan menjadi baik dan memberikan suatu keharmonisan bagi pembelian ulang dan terciptanya loyalitas pelanggan.

Penelitian Sedjai Asma (2018) pada konsumen TurkishAirlines menunjukan bahwa terdapat hubungan positif yang kuat yang signifikan secara statistik antara kepuasan pelanggan dan loyalitas. Hal tersebut terjadi karena ketika konsumen puas, mereka akan menyarankan orang lain dan juga akan kembali melakukan perjalanan dengan Turkish Airlines.

Penelitian yang dilakukan oleh Tjahjaningsih (2013); Sembiring et al. (2014); Irawan dan Japarianto (2013); dan Raharjo (2013) menyatakan bahwa kepuasan pelanggan berpengaruh positif dan signifikan terhadap loyalitas pelanggan. Berdasarkan hasil penelitian yang telah dikemukakan, maka pada penelitian ini hipotesis yang dapat ditarik sebagai berikut:

$\mathrm{H}_{5}$ : Kepuasan pelanggan berpengaruh positif dan signifikan terhadap loyalitas pelanggan.

Berry (2007:1) menyebutkan sepuluh faktor penentu kepuasan yang mempengaruhi perilaku kepuasan pelanggan, salah satunya adalah kualitas produk. Santoso (2009:145) mengatakan bahwa pelanggan yang terpuaskan akan dengan senang hati menyampaikan kabar positif tentang perusahaan. Kualitas produk yang baik akan menimbulkan keinginan pelanggan untuk melakukan pembelian ulang.

Muhammad Rizwan et al. (2014) menyatakan ketika kualitas produk meningkat maka kepuasan juga meningkat dan pelanggan akan setia sehingga terjadi loyalitas pelanggan terhadap produk. Pandangan menurut Lumintang dan Jopie (2015) dalam penelitiannya menyatakan bahwa kualitas produk berpengaruh 
signifikan terhadap kepuasan pelanggan dan arahnya positif. Kurniawati et al. (2014) menyatakan adanya pengaruh signifikan dari kepuasan pelanggan terhadap loyalitas pelanggan. Fang (2014) melakukan penelitian yang menunjukkan bahwa kualitas berpengaruh terhadap loyalitas pelanggan namun tidak berpengaruh secara langsung terhadap loyalitas pelanggan. Sehingga kualitas produk akan berpengaruh positif dan signifikan terhadap loyalitas ketika pelanggan merasakan kepuasan terhadap produk terlebih dahulu. Berdasarkan hasil penelitian yang telah dikemukakan, maka pada penelitian ini hipotesis yang dapat ditarik sebagai berikut:

$\mathrm{H}_{6} \quad$ : Kepuasan pelanggan berperan positif dan signifikan dalam memediasi kualitas produk terhadap loyalitas pelanggan.

Harga menurut Arnindita (2016) adalah kepuasan yang penting karena mereka akan mendapatkan value for money yang tinggi sehingga dapat membuat pelanggan loyal. Pelanggan yang loyal dapat ditunjukkan dengan melakukan pembelian ulang. Hal ini ditunjukan pada jurnal Asead dan Noermijati (2013) menyebutkan bahwa harga tidak berpengaruh terhadap loyalitas pelanggan secara langsung, tetapi harga memiliki pengaruh terhadap loyalitas pelanggan secara tidak langsung melalui kepuasan pelanggan sehingga variabel kepuasan pelanggan sebagai variable mediasi.

$\mathrm{H}_{7} \quad$ : Kepuasan pelanggan berperan positif dan signifikan dalam memediasi persepsi harga terhadap loyalitas pelanggan.

\section{METODE PENELITIAN}


Lokasi penelitian yang dipilih oleh peneliti terletak di Kota Denpasar. Lokasi ini dipilih karena outlet Miniso di Bali pertama kali dibuka di Kota Denpasar yaitu pada tanggal 19 September 2017.

Penelitian ini menggunakan 15 indikator dan peneliti memilih angka 7 dari rentang ukuran sampel terbaik yang disarankan untuk mengukur multivariate yaitu 5 - 10 observasi setiap parameter yang diperkirakan. Dengan demikian, responden yang dibutuhkan dalam penelitian ini adalah 105 responden.

$$
\text { (15 indikator } \mathrm{x} 7=105 \text { responden) }
$$

Teknik analisis statistik infrensial yang digunakan dalam penelitian ini adalah teknik analisis jalur (path analysis). Teknik analisis jalur ini dapat didefinisikan sebagai perluasan dari analisis linier berganda dalam memperkirakan hubungan kausalitas antara yang telah ditetapkan berdasarkan teori. Dasar perhitungan koefisian jalur adalah analisis korelasi dan regresi dan dalam perhitungannya menggunakan software dengan program SPSS for windows 24.0. . Dalam hal ini dua persamaan tersebut adalah.

$$
\begin{aligned}
& \mathrm{Y}_{1}=\beta_{1} \mathrm{X}_{1}+\beta_{2} \mathrm{X}_{2+} \mathrm{e}_{1} \\
& Y_{2}=\beta_{3} X_{1}+\beta_{4} X_{2}+\beta_{5} Y_{1}+e_{2}
\end{aligned}
$$

Keterangan :
$\mathrm{X}_{1} \quad$ : Kualitas Produk
$\mathrm{X}_{2} \quad$ : Persepsi Harga
Y : Kepuasan Pelanggan
M : Loyalitas Pelanggan
$\beta_{1}, \beta_{2}, \beta_{3}, \beta_{4}, \beta_{2}$ : Koefisien dari masing - masing variabel
$\mathrm{e}_{1 .} \mathrm{e}_{2}$ : Error of term atau variabel penganggu 
Pengujian hipotesis mediasi dilakukan dengan metode VAF. menghitungVariance Accounted For (VAF) dengan rumus:

$$
V=\begin{array}{ccccc}
P & n T & L & \\
\hline P & n L & +P & n T & L
\end{array}
$$

\section{HASIL DAN PEMBAHASAN}

Untuk perhitungan koefisien jalur dilakukan dengan menggunakan software SPSS 24.0. Hasil dari persamaan struktur 1 disajikan pada Tabel 2.

Tabel 2.

Hasil Analisis Jalur Struktur I

\begin{tabular}{lccc}
\hline \multicolumn{1}{c}{ Variabel } & Standardized Coefficients & t hitung & Sig. uji t \\
\hline Kualitas Produk (X1) & 0,507 & 6,401 & 0,000 \\
Persepsi Harga (X2) & 0,360 & 4,547 & 0,000 \\
R Square & 0,618 & & \\
F Statistik & 82,630 & & \\
Signifikansi Uji F & 0,000 & & \\
\hline
\end{tabular}

Sumber : Data Diolah, 2018

Berdasarkan hasil Tabel 1 maka persamaan struktur 1 adalah sebagai berikut:

Persamaan Struktur 1

$$
\begin{array}{ll}
\mathrm{M} & =\beta_{1} \mathrm{X} 1+\beta_{2} \mathrm{X} 2+\mathrm{e}_{1} \\
\mathrm{M} & =0,507 \mathrm{X} 1+0,360 \mathrm{X} 2+\mathrm{e}_{1} \\
\varepsilon_{1}\left(\text { error }_{1}\right) & =\sqrt{1-k^{2}} \ldots \ldots \ldots \ldots \ldots \ldots \ldots \ldots \ldots \ldots \ldots \ldots \\
& =\sqrt{1-0,618} \\
& =0,618
\end{array}
$$

Hasil perhitungan pada Tabel 2 menemukan tingkat signifikansi kualitas produk sebesar $0,000<0,05$, dengan nilai beta 0,507 , maka dapat dikatakan bahwa kualitas produk berpengaruh positif dan signifikan terhadap kepuasan pelanggan pada konsumen produk Miniso di Kota Denpasar. 
Ketika perusahaan mampu memberikan produk sesuai dengan yang diharapkan konsumen maka konsumenakan merasa puas dengan kualitas produk dari perusahaan itu sendiri. Setiap perusahaan sebaiknya mengetahui apa yang sedang dibutuhkan oleh konsumen, dan melakukan inovasi secara berkelanjutan agar konsumen tidak merasa bosan dengan produk yang ditawarkan.

Hasil penelitian ini sesuai dengan rumusan hipotesis yang menyatakan bahwa kualitas produk berpengaruh positif dan signifikan terhadap kepuasan pelanggan pada konsumen produk Miniso di Kota Denpasar yang artinya semakin baik kualitas produk yang ditawarkan oleh produk Miniso maka akan membuat semakin tinggi tingkat kepuasan pelanggan yang dirasakan pelanggan produk Miniso di kota Denpasar. Hasil penelitian ini mendukung penelitian yang dilakukan oleh Haryanto (2013), Lasander (2013), Ismail et al. (2016), dan Tumangkeng (2013).

Hasil perhitungan pada Tabel 2 menemukan tingkat signifikansi persepsi harga sebesar $0,000<0,05$, dengan nilai beta 0,360 , maka dapat dikatakan bahwa persepsi harga berpengaruh positif dan signifikan terhadap kepuasan pelanggan pada konsumen produk Miniso di Kota Denpasar.

Persepsi harga tentu saja dilihat dari berbagai persepsi konsumen. Konsumen akan membanding dengan produk yang mereka terima dengan harga yang harus dibayarkan guna mendapatkan produk tersebut. Konsumen akan mempersepsikan harga yang dibayarkan adalah terjangkau apabila harga sesuai dengan pengharapan konsumen tersebut. 
Made Indira Sari Parthady, Peran Kepuasan Pelanggan....

Hasil penelitian ini sesuai dengan rumusan hipotesis yang menyatakan bahwa persepsi harga berpengaruh positif dan signifikan terhadap kepuasan pelanggan pada konsumen produk Miniso di Kota Denpasar yang artinya semakin konsumen mempersepsikan harga dari produk Miniso murah dan terjangkau maka akan membuat semakin tinggi tingkat kepuasan pelanggan yang dirasakan pelanggan produk Miniso di kota Denpasar. Hasil penelitian ini mendukung penelitian yang dilakukan oleh Ismail et al. (2016), Ehsani dan Ehsani (2015), Arnindita (2016) dan Fata (2015).

Berikut ini adalah Tabel 3output regression SPSS 24.0 untuk membuat persamaan struktur 2:

Tabel 3.

Hasil Analisis Jalur Struktur II

\begin{tabular}{lccc}
\hline \multicolumn{1}{c}{ Variabel } & Standardized Coefficients & t hitung & Sig. uji t \\
\hline Kualitas Produk (X1) & 0,199 & 2,594 & 0,011 \\
Persepsi Harga (X2) & 0,283 & 3,974 & 0,0000 \\
Kepuasan Pelanggan (M) & 0,479 & 5,904 & 0,000 \\
R Square & 0,746 & \\
F Statistik & 98,968 & \\
Signifikansi Uji F & 0,000 & \\
\hline
\end{tabular}

Sumber : Data diolah, 2018

Persamaan Struktur 2

$$
\begin{aligned}
\mathrm{Y} & =\beta_{3} \mathrm{X}_{1}+\beta_{4} \mathrm{X}_{2}+\beta_{5} \mathrm{M}+\mathrm{e}_{2} \ldots \ldots \ldots \ldots \ldots \ldots \\
\mathrm{Y} & =0,199 \mathrm{X}_{1}+0,283 \mathrm{X}_{2}+0,479 \mathrm{M}+\mathrm{e}_{2} \\
\varepsilon_{2}(\text { error }) & =\sqrt{1-R^{2}} \\
& =\sqrt{1-0,746} \\
& =0,503
\end{aligned}
$$

Berdasarkan hasil analisis $\varepsilon 1$ dan $\varepsilon 2$ maka dapat dihitung koefisien determinasi

total sebagai berikut :

$$
\begin{aligned}
& \mathrm{R}^{2}{ }_{\mathrm{m}}=1-\left(\varepsilon_{1}\right)^{2}\left(\varepsilon_{2}\right)^{2} \ldots \ldots \ldots \ldots \ldots \ldots \ldots \ldots \\
& =1-(0,618)^{2}(0,503)^{2} \\
& =1-(0,381)(0,253)=0,903
\end{aligned}
$$


Nilai determinasi total sebesar 0,903 mempunyai arti bahwa sebesar 90,3 persen variasi Loyalitas Pelanggan dipengaruhi oleh variasi Kualitas Produk, Persepsi Harga, dan Kepuasan Pelanggan, sedangkan sisanya sebesar 9,7 persen dijelaskan oleh faktor lain yang tidak dimasukkan ke dalam model.

Hasil perhitungan pada Tabel 3 menemukan tingkat signifikansi kualitas produk sebesar $0,011<0,05$, dengan nilai beta 0,199 , maka dapat dikatakan bahwa kualitas produk berpengaruh positif dan signifikan terhadap loyalitas pelanggan pada konsumen produk Miniso di Kota Denpasar.

Kualitas produk itu sendiri dapat membuat bagaimana pandangan konsumen mengenai produk tersebut yang nantinya akan melakukan pembelian ulang. Benak konsumen terhadap suatu produk menimbulkan apakah konsumen akan loyal atau tidak terhadap produk tersebut. Konsumen yang merasa bahwa kualitas produk dari suatu perusahaan sangat bermanfaat baginya, nantinya akan membuat konsumen melakukan pembelian ulang dan bahkan akan menimbulkan kesetiaan konsumen tersebut pada produk itu sendiri.

Hasil penelitian ini sejalan dengan penelitian Caesar (2015), Kurniawati et al. (2014), Sembiring et al. (2014), Irawan dan Japarianto (2013), dan Pongoh (2013) yang mendapatkan hasil bahwa kualitas produk yang dirasakan oleh konsumen berpengaruh signifikan terhadap loyalitas pelanggan.

Berdasarkan dari hasil pengujian hipotesis keempat, diperoleh hasil perhitungan pada Tabel 3 menemukan tingkat signifikansipersepsi harga sebesar $0,000<0,05$, dengan nilai beta 0,283 , maka dapat dikatakan bahwa persepsi harga 
berpengaruh positif dan signifikan terhadap loyalitas pelanggan pada konsumen produk Miniso di Kota Denpasar.

Harga yang sesuai dengan produk yang ditawarkan akan membuat bagaimana nantinya perilaku pembelian ulang konsumen. Loyalitas merek konsumen terhadap suatu perusahaan dilihat dari tingkat pembelian ulang, konsumen yang melakukan pembelian ulang secara terus menerus menandakan adanya tingkat kesukaan konsumen terhadap produk tersebut.

Hasil penelitian ini sejalan dengan penelitian yang dilakukan Asadi et al. (2014); Fata (2015); dan Nur Laely (2016) yang mendapatkan hasil bahwa persepsi harga yang dirasakan oleh konsumen berpengaruh signifikan terhadap loyalitas pelanggan.

Berdasarkan dari hasil pengujian hipotesis kelima, diperoleh hasil perhitungan pada Tabel 3 menemukan tingkat signifikansikepuasan pelanggan sebesar $0,000<0,05$, dengan nilai beta 0,479 , maka dapat dikatakan bahwa kepuasan pelanggan berpengaruh positif dan signifikan terhadap loyalitas pelanggan pada konsumen produk Miniso di Kota Denpasar.

Tingkat loyalitas konsumen dilihat dari tingkat pembelian ulangnya terhadap suatu produk. Konsumen yang melakukan pembelian ulang secara terus menerus mengindikasikan bahwa konsumen puas dengan produk yang ditawarkan perusahaan tersebut. Tujuan utama dari suatu perusahaan adalah bagaimana menciptakan kepuasan pelanggan, sehingga nantinya akan menimbulkan sikap loyal konsumen terhadap merek suatu perusahaan. 
Hasil penelitian ini didukung oleh penelitian sebelumnya, seperti pada penelitian Tjahjaningsih (2013) dan Sembiring et al. (2014) bahwa kepuasan berpengaruh positif signifikan terhadap loyalitas merek. Senada dengan penelitian yang dilakukan Irawan dan Japarianto (2013) dan Raharjo (2013) terdapat pengaruh positif signifikan antara kepuasan pelanggan terhadap loyalitas pelanggan. Disimpulkan bahwa kepuasan itu sendiri adalah pembentuk loyalitas pelanggan pada setiap konsumen.

Uji sobel Pengaruh Kualitas Produk (X1) Melalui Kepuasan Pelanggan (M) terhadap Loyalitas Pelanggan (Y) sebagai berikut:

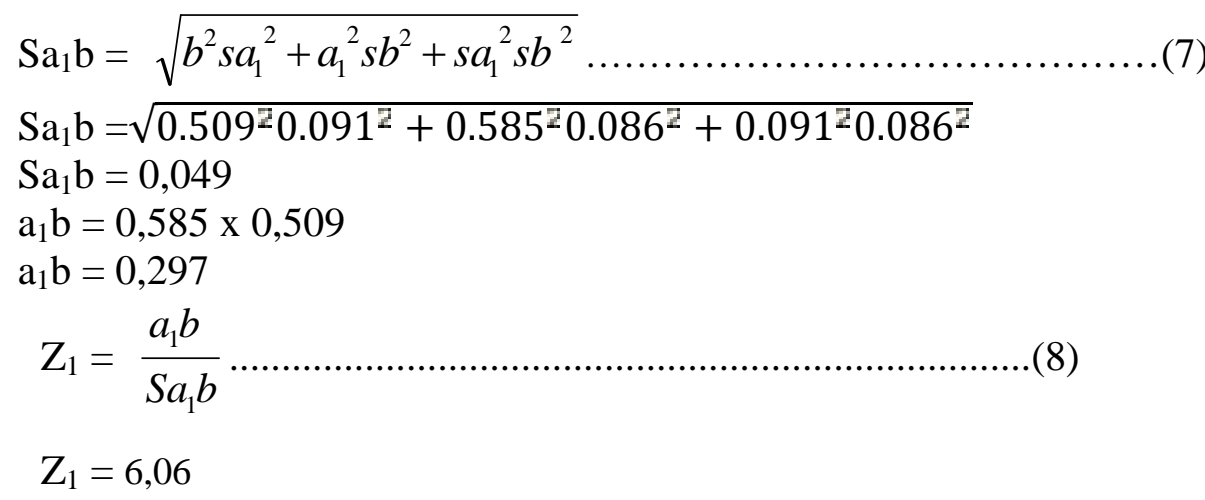

Hasil perhitungan didapatkan perbandingan nilai z hitung sebesar 6,06> z tabel sebesar 1,96, maka hipotesis $\mathrm{H}_{6}$ diterima yang artinya kepuasan pelanggan mampu memediasi secara signifikan pengaruh kualitas produk terhadap loyalitas pelanggan. Hal ini menunjukkan bahwa jika kualitas produk yang dirasakan tersebut meningkat maka akan meningkatkan kepuasan pelanggan, apabila kepuasan pelanggan tersebut meningkat maka secara tidak langsung akan meningkatkan loyalitas pelanggan pada konsumen produk Miniso. Berdasarkan hasil uji VAF perhitungan dari Pengaruh Kualitas Produk (X1) melalui Kepuasan 
Pelanggan (M) terhadap Loyalitas Pelanggan (Y) diperoleh Nilai VAF sebesar 55 persen, nilai ini berada di antara 20 persen hingga 80 persen, maka dapat dikategorikan sebagai pemediasi parsial (partial mediation).

Hasil penelitian ini sesuai dengan rumusan hipotesis yang menyatakan bahwa kepuasan pelanggan mampu memediasi pengaruh kualitas produk terhadap loyalitas konsumen produk Miniso di Kota Denpasar. Hasil penelitian ini mendukung penelitian yang dilakukan oleh Muhammad Rizwan et al. (2014) yang menyatakan ketika kualitas produk meningkat maka kepuasan juga meningkat dan pelanggan akan setia sehingga terjadi loyalitas pelanggan terhadap produk.

Uji VAF Pengaruh Kualitas Produk (X1) Melalui Kepuasan Pelanggan (M) terhadap Loyalitas Pelanggan (Y) sebagai berikut:

$$
\begin{aligned}
& \mathrm{VAF}=\begin{array}{ccccc}
P & h T & L & & \\
P & n L & +P & n T & L
\end{array} \\
& \mathrm{VAF}=\frac{\mathrm{U}, 2}{\mathrm{U,1}+\mathrm{U}, 2} \\
& \mathrm{VAF}=0,550
\end{aligned}
$$

Berdasarkan perhitungan dari Pengaruh Kualitas Produk (X1) Melalui Kepuasan Pelanggan (M) terhadap Loyalitas Pelanggan (Y) diatas diperoleh Nilai VAF sebesar 55 persen, nilai ini berada di antara 20 persen hingga 80 persen, maka dapat dikategorikan sebagai pemediasi parsial (partial mediation)

Uji VAF Pengaruh Persepsi Harga (X2) Melalui Kepuasan Pelanggan (M) terhadap Loyalitas Pelanggan (Y) sebagai berikut:

$$
\mathrm{VAF}=\begin{array}{llllll}
P & n T & L & & \\
\hline P & n L & n+P & n t & L
\end{array}
$$




$$
\begin{aligned}
& \mathrm{VAF}=\frac{\mathrm{u}, 1}{0,2+0,1} \\
& \mathrm{VAF}=0,386
\end{aligned}
$$

Berdasarkan perhitungan dari Pengaruh Persepsi Harga (X2) Melalui Kepuasan Pelanggan (M) terhadap Loyalitas Pelanggan (Y) diatas diperoleh Nilai VAF sebesar 38,6 persen, nilai ini berada di antara 20 persen hingga 80 persen, maka dapat dikategorikan sebagai pemediasi parsial (partial mediation).

Hasil perhitungan didapatkan perbandingan nilai z hitung sebesar 4,48> z tabel sebesar 1,96, maka hipotesis $\mathrm{H}_{7}$ diterima yang artinya kepuasan pelanggan mampu memediasi secara signifikan pengaruh persepsi harga terhadap loyalitas pelanggan. Hal ini menunjukkan bahwa jika persepsi harga di benak konsumen adalah murah dan terjangkau maka akan meningkatkan kepuasan pelanggan, apabila kepuasan pelanggan tersebut meningkat maka secara tidak langsung akan meningkatkan loyalitas pelanggan pada konsumen produk Miniso. Berdasarkan perhitungan dari pengaruh persepsi harga (X2) melalui kepuasan pelanggan (M) terhadap loyalitas pelanggan (Y) diperoleh nilai VAF sebesar 38,6 persen, nilai ini berada diantara 20 persen hingga 80 persen, maka dapat dikategorikan sebagai pemediasi parsial (partial mediation).

Hasil penelitian ini sesuai dengan rumusan hipotesis yang menyatakan bahwa kepuasan pelanggan mampu memediasi pengaruh persepsi harga terhadap loyalitas konsumen produk Miniso di Kota Denpasar. Hasil penelitian ini mendukung penelitian yang dilakukan oleh Noermijati (2013) yang menyatakan harga memiliki pengaruh terhadap loyalitas pelanggan secara tidak langsung melalui kepuasan pelanggan. 
Implikasi pada penelitian dibagi menjadi dua bagian, yaitu implikasi teoritis dan implikasi praktis. Pada penelitian ini, implikasi praktis dan teoritis dijelaskan secara rinci, yaitu sebagai berikut:

Berdasarkan penelitian yang sudah dilakukan sehingga dapat diketahui bahwa secara teoritis, penelitian ini secara keseluruhan dapat mendukung beberapa teori yang telah ada sebelumnya. Penelitian ini diharapkan dapat memberikan kontribusi empiris tentang hubungan antara variabel kualitas produk, persepsi harga, kepuasan pelanggan danloyalitas pelanggan bagi pengembangan ilmu pemasaran. Pengolahan data dilakukan dengan teknik analisis jalur (path analysis) untuk menguji model antar variabel-variabel yang telah ditetapkan sebelumnya berdasarkan teori. Selain itu penelitian ini juga menggunakan Uji Sobel untuk menguji kekuatan pengaruh tidak langsung variabel kualitas produk $\left(\mathrm{X}_{1}\right)$ dan persepsi harga $\left(\mathrm{X}_{2}\right)$ terhadap variabel loyalitas pelanggan $(\mathrm{Y})$ melalui variabel kepuasan pelanggan(M). Hasil penelitian ini diharapkan dapat digunakan untuk memperkaya referensi dan ilmu pengetahuan yang berkaitan dengan variabel kualitas produk, persepsi harga, kepuasan pelanggan, dan loyalitas pelanggan.

Hasil penelitian ini diharapkan dapat digunakan bagi manajemen perusahan Miniso dalam merancang strategi pemasaran berdasarkan kualitas produk dan persepsi harga guna meningkatkan kepuasan pelanggann dan loyalitas pelanggan terhadap produk Miniso. Strategi yang dapat dilakukan oleh perusahaan yaitu dengan meningkatkan kualitas produk dan terus melakukan inovasi sehingga 
Miniso menjadi populer agar konsumen menjadi puas dan setia terhadap produk Miniso.

Beberapa keterbatasan dari penelitian ini adalah ruang lingkup pada penelitian ini hanya pada konsumen Miniso di Kota Denpasar, sehingga pada penelitian ini tidak dapat digeneralisasi untuk konsumen Miniso di luar Kota Denpasar. Pada penelitian selanjutnya akan lebih baik apabila cangkupan ruang penelitiannya diperluas agar dapat melihat penerapan kualitas produk dan persepsi harga secara keseluruhan.Penelitian ini hanya dilakukan dalam titik waktu tertentu (cross section), sedangkan lingkungan bersifat sangat dinamis sehingga diharapkan penelitian dapat dilakukan kembali pada masa akan datang.

\section{SIMPULAN DAN SARAN}

Berdasarkan hasil pembahasan yang telah dilakukan dalam penelitian, dapat disimpulkan bahwa kualitas produk memiliki pengaruh positif dan signifikan dengan kepuasan pelanggan, maka semakin baik kualitas produk Miniso maka semakin tinggi pula tingkat kepuasan pelanggan dirasakan.

Persepsi harga memiliki pengaruh positif dan signifikan dengan kepuasan pelanggan, maka hal tersebut membuktikan bahwa semakin konsumen memiliki persepsi harga yang baik terhadap produk Miniso maka semakin tinggi tingkat kepuasan pelanggan dirasakan.

Kualitas produk memiliki pengaruh positif dan signifikan dengan loyalitas pelanggan. Hal tersebut berarti semakin baik kualitas produk yang diberikan oleh 
Miniso maka semakin tinggi tingkat loyalitas pelanggan pada konsumen produk Miniso.

Persepsi harga berpengaruh positif dan signifikan dengan loyalitas pelanggan. Hal tersebut berarti semakin baik persepsi harga yang diberikan oleh Miniso maka semakin tinggi tingkat loyalitas pelanggan pada konsumen produk Miniso.

Kepuasan pelanggan memiliki pengaruh positif dan signifikan dengan loyalitas pelanggan. Hal tersebut berarti semakin tinggi kepuasan pelanggan yang dirasakan oleh konsumen produk Miniso maka semakin tinggi pula tingkat loyalitas pelanggan pada konsumen produk Miniso.

Kepuasan pelanggan berpengaruh positif dan signifikan dalam memediasi pengaruh kualitas produk dengan loyalitas pelanggan. Hal ini menunjukan bahwa kualitas produk Miniso yang dirasakan konsumen produk Miniso di Kota Denpasar akan memberikan dampak yang signifikan dengan loyalitas pelanggan jika dimediasi oleh kepuasan pelanggan, yang berarti bahwa loyalitas pelanggan pada konsumen produk Miniso di Kota Denpasar sangat tergantung pada tingkat kualitas produk yang dirasakan dan juga tingkat kepuasan pelanggan .

Kepuasan pelanggan berpengaruh positif dan signifikan dalam memediasi pengaruh persepsi harga dengan loyalitas pelanggan. Hal ini menunjukan bahwa persepsi harga yang dirasakan konsumen terhadap produk Miniso di Kota Denpasar akan memberikan dampak yang signifikan dengan loyalitas pelanggan jika dimediasi oleh kepuasan pelanggan, yang berarti bahwa loyalitas pelanggan 
pada konsumen prouk Miniso di Kota Denpasar sangat tergantung pada bagaimana persepsi hara yang dirasakan dan juga tingkat kepuasan pelanggan.

Berdasarkan kesimpulan tersebut, maka saran yang dapat diberikan bagi pihak Miniso adalah agar kedepannya lebih memingkatkan kualitas produk yaitu dengan memperhatikan daya tahan dari produk Miniso itu sendiri, kemudian dari segi persepsi harga Miniso agar kedepannya dapat memberikan pemahaman mengenai harga yang dibayarkan konsumen untuk mendapatkan produk Miniso untuk setiap transaksinya, dan dari segi kepuasan pelanggan Miniso perlu menigkatkan kualitas produknya dibandingkan dengan pesaing agar lebih memberikan kepuasan pada konsumen, yang terakhir dari segi loyalitas pelanggan, Miniso perlu meningkatkan respon konsumen agar berkata positif mengenai produk Miniso.

Saran untuk penelitian selanjutnya, diharapkan agar memperluas ruang lingkup penelitian dengan konsumen yang tersebar di berbagai wilayah, baik skala regional maupun nasional dengan produk yang lebih dikenal masyarakat luas. Penelitian selanjutnya juga dapat mengubah objek penelitiannya. Dalam penelitian di masa mendatang juga perlu dipertimbangkan untuk menggunakan variabel lain sehingga dapat memperkaya informasi yang diperoleh.

\section{REFERENSI}

Amir Mahmud, Kamaruzaman Jusoff and St. Hadijah. (2013). The Effect of Service Quality and Price on Satisfaction and Loyalty of Customer of Commercial Flight Service Industry. World Applied Sciences Journal. 23 (3), pp: 354-359.

Andra Miranthi Idris. (2017). Pengaruh Citra Perusahaan, Kualitas Layanan, dan Persepsi Harga Terhadap Minat Beli Ulang Layanan New Atlas Taksi 
Semarang Melalui Kepuasan Pelanggan Sebagai Variabel Intervening. Diponegoro Journal Of Management. 6 (3), pp: 1-8.

Ali Asadi Javad Khazaei Pool and Mohammad Reza Jalilvand. (2014). The Effect of Perceived Price Fairness Through Satisfaction and Loyalty on International Tourists' Price Acceptance of Islamic-Iranian Art Products. Education, Business and Society: Contemporary Middle Eastern Issues. 7(4), 201-215.

Caesar Andreas. (2016).Pengaruh Kualitas Produk Terhadap Loyalitas Pelanggan Dengan Kepuasan Sebagai Variabel.Jurnal Ilmu dan Riset Manajemen, 5 (5), pp: 2-13.

Edward Markwei Martey. (2014). The Relationship between Customer Retention and Customer Loyalty in the Restaurant Industry in Ghana. International Journal of Research. 1(8), 51-66.

Shan Fang. (2014). Empirical Study of Influential Elements of University Students' E-satisfaction. International Journal of Business and Social Science. 5(6), 122-129.

Fata, Khairul. (2015). Pengaruh Harga, Citra Merek, Dan Fitur Terhadap Kepuasan pelanggan Serta Dampaknya Pada Loyalitas Merek (Studi Kasus Produk Handphone Samsung Di Banda Aceh). Jurnal Kebangsaan. 4 (7), pp: 40-46.

Haryanto, Resty Avita. (2013). Strategi Promosi, Kualitas Produk, Kualitas Layanan Terhadap Kepuasan Pelanggan Pada Restoran Mc donald'sManado. Jurnal. Manado: Fakultas Ekonomi dan Bisnis, Universitas Sam Ratulagi, 1 (4), pp: 1465-1473.

Howat Gary, Guy Assaker. (2013). The Hierarchial Effects of Perceived Quality on Perceived Value, Satisfaction, and Loyalty: Empirical Result form Public, Outdoor Aquatic Centres in Australia. Sport Management Review. 16, pp: 268-284.

Ismail Razak, Nazief Nirwanto dan Boge Triatmanto. (2016). The Impact Of Product Quality and Price on Customer Satisfaction With The Mediator of Customer Value. Journal of Marketing and Consumer Research. 30, pp: 2422-8451.

Kotler dan Amstrong, G. (2012). Prinsip - prinsip Pemasaran. Edisi 13. Penerbit, PT, Indeks. Jakarta. 
Kurniawati dewi, Suharyono dan Andriani Kusumawati. (2014). Pengaruh Citra Merek dan Kualitas Produk Terhadap Kepuasan dan Loyalitas Pelanggan (Studi pada Pelanggan KFC Cabang Kawi Malang). Jurnal Administrasi Bisnis (JAB), 14 (2), pp: 1-9.

Lasander, Christian. (2013). Citra Merek, Kualitas Produk dan Promosi Pengaruhnya terhadap Kepuasan Konsumen pada Makanan Tradisional (Survey pada Industri Rumah Tangga Dodol Daging Pala Audia di Tahuna Kab. Sangihe). Jurnal EMBA, 1 (3), pp: 284-293.

Lovelock, Christopher H. (2016). Manajemen Pemasaran Jasa. Jakarta: Indeks.

LumintangG. danJopieR.(2015). Analisis Kualitas Produk Dan Kualitas. Layanan Terhadap Kepuasan Konsumen Pada Holland Bakery Boulevard. Manado. Jurnal EMBA, 3 (1), pp: 1291-1302.

Marakanon, Lalinthorn and Vinai Pajakajornsak. (2017). Perceived Quality, Perceived Risk and Customer Trust Affecting Customer Loyalty of Environmentally Friendly Electronics Products. Kasetsart Journal of Social Sciences. 3(8), 24-30.

Malik Yaqoob, dan Aslam. (2012). The Impact of Price Perception, Service Quality, and Brand Image on Custumer Loyalty (Study of Hospitality Industry in Pakistan Interdisciplinary. Journal of Contempory Research in Business. 4(5), 487-505.

Muhammad Rizwan, Muhammad Abu Umair, dan Anser Fiaz. (2014). Determinants of Customer Satisfaction and its impact on Customer loyalty in Nokia brand. Journal of Sociological Research. 5 (1), pp: 1948-5468.

Nuridin. 2018. Effect of Service Quality and Quality of Products to Customer loyalty with Customer Satisfaction as Intervening Variable in PT. Nano Coating Indonesia. International Journal of Business and Applied Social Science. 4(1), 19-31.

Nur Laely. (2016). Analisis Pengaruh Kepercayaan dan Harga Terhadap Loyalitas Pelanggan Dimediasi Kepuasan Pada PT. Telkomsel di Kota Kediri. Jurnal Ilmu Ekonomi \& Manajemen, 3 (2), pp: 61 - 74.

Noor Hafiza Mohammed, Sholehah Abdullah, Suzila Mat Salleh, Kartini Mat Rashid, Siti Fatimah Mardiah Hamzah, Najmiah Sudin. (2017). Relationship among Service and Product Quality, and Price in Establishing Customer Satisfaction. Journal of Applied Environmental and Biological Sciences. 7 (5), pp: 45-50. 
Peter Halim, Bambang Swasto, Djamhur Hamid, M. Riza Firdaus. (2014). The Influence of Product Quality, Brand Image, and Quality of Service to Customer Trust and Implication on Customer Loyalty (Survey on Customer Brand Sharp Electronics Product at the South Kalimantan Province), European Journal of Business and Management, 6 (29), pp: 159-166.

Pongoh, Melysa Elisabeth. (2013). Kualitas Pelayanan, Kualitas Pelayanan, Kualitas Produk dan Harga Pengaruhnya Terhadap Loyalitas Pelanggan Kartu AS Telkomsel di Kota Manado. Jurnal EMBA, 1 (4), pp: 86-94.

Praharsi Yugowati, Nofi Erni, dan Bohal Juanda Sinambela. (2015). Analisa Faktor-faktor yang Mempengaruhi Kepuasan Pelanggan terhadap Produk Air Minum (Studi Kasus: Perusahaan CV.OEN Jaya). Jurnal Metris, 16 (1), pp: $35-44$.

Prasastono Ndaru, Ema Rahmawati, Sri Yulianto Fajar Pradapa. (2017). Effect of Price, Quality Products and Brand Image Purchase Decisions Getuk Pisang “Sari Madu” Kediri. Jurnal Unisbank. 3 (3), pp: 324-337.

Pudyanarti Sri Kuning dan Tri Yuniati. (2016). Pengaruh Keunggulan Kompetitif dengan Loyalitas Pelanggan Terhadap Ekspansi Pasar pada Hypermart City of Tomorrow (CITO) Surabaya. Jurnal Ilmu dan Riset Manajemen. 5(9), 1-19.

Raharjo, A. (2013). Pengaruh Kualitas Produk Terhadap Loyalitas Konsumen yang Dimediasi oleh Kepuasan Konsumen Pengguna Kartu As. Jurnal Manajemen. 9 (1), pp: 30-44.

Rimawan, Erry., Ali Mustofa, Angga Dwi Mulyanto. (2017). The Influence of Product Quality, Service Quality and Trust on Customer Satisfaction and Its Impact on Customer Loyalty (Case Study PT ABC Tbk). International Journal of Scientific \& Engineering Research.8 (7), pp: 2229-5518.

Rizwan, M., Qoyyum, M., Qadeer, W., \& Javed, M. (2014). The Impact On Branded Product On Consumer Purchase Intentions. Journal of Public Administration and Governance. 4(3), pp: 57-74.

Surya Ananta Wijaya dan Nurcaya. (2016). Kepuasan Pelanggan Memediasi Kualitas Produk dan Kewajaran Harga Terhadap Loyalitas Merek McDonals di Kota Denpasar. E-Jurnal Manajemen Unud. 6 (3), pp: 126.

Samah, Irza., Intan Maizura, Mohd Juraij, Abdul Rahman, Ahmar Ali, Fazlee Sham. (2015). The Roles of Price Perceptiom and Phisycal Enviroment 
in Determining Customer Loyalty: Evidence from Fast Food Restaurant of Malaysia.International Journal of Development Reaserch. 5 (5), pp: 4366-4370.

Sedjai Asma, Maliki Samir Baha Dine, Berbar Wafaa dan Ainous Redouan. (2018). The Effect of Perception Quality/Price of Service on Satisfaction and Loyalty Algerians Customers Evidence Study Turkish Airlines. International Journal Economic Management Sci. 7 (1), pp: 2162-6359.

Sembiring Janita Inka Suharyono dan Kusumawati Andriani. (2014). Pengaruh Kualitas Produk dan Kualitas Pelayanan Terhadap Kepuasan Pelanggan Dalam Membentuk Loyalitas Pelanggan (Studi Pada Pelanggan McDonald 's MT. Haryono Malang). Jurnal Administrasi Bisnis. 15 (1), pp: $1-9$.

Sangadji, Etta Mamang \& Sopiah. (2013). Perilaku Konsumen - Pendekatan Praktis disertai Himpunan Jurnal Penelitian. Yogyakarta: ANDI.

Tumangkeng, Gerardo Andrew. (2013).Pengaruh Kualitas Produk, Suku Bunga dan Kualitas Pelayanan Terhadap Kepuasan Pelanggan KPR pada Bank BTN Cabang Manado. Jurnal EMBA, 1 (4), pp: 78-85.

Zohaib Ahmed, Muhammad Rizwan, Mukhtar Ahmad, Misbahul Haq. (2014). Effect of Brand Trust and Customer Satisfaction on Brand Loyalty in Bahawalpur. Journal of Sociological Research. 5 (1), pp: 306-326. 